\title{
Equipment
}

\section{Patient data}

\section{management systems in anaesthesia: an emerging technology}

The purpose of this review is to define the expectations of an on-line automatic patient data management system (PDMS) into anaesthesia work-stations in and around the operating room suite. These expectations are based on review of available information in the medical literature, and trials of several systems that are available commercially, three of them in a more detailed fashion (i.e., Informatics ${ }^{\circledR}$, Datex ${ }^{\circledR}$ and North American Drager ${ }^{\circledR}$ ). The ideal PDMS should:

- communicate with and capture the information from different monitors, anaesthesia machines and electronic gadgets (e.g., infusion pumps) used in the operating room (OR), while presenting selected relevant values and trends on a screen.

- inform the anaesthetist of deviations from preselected limits of physiological and technical values. In the future, the system will hopefully be upgraded to include an algorithm-based decision support system.

- communicate, with the haspital mainframe computer, and automatically transfer demographic data, laboratory and imaging results, and records obtained during preoperative consultations.

- at the end of each anaesthetic procedure, create an anaesthetic record with relevant data automatically collected by the system, as well as that which was entered manually by the physician during the procedure. $A$ copy of this anaesthesia file must be kept on a computerized archive system. None of the systems so far evaluated fulfilled all our expectations. We have therefore adopted an approach for the gradual introduction of such a system into our OR environment over the next two to five years, during which expected improvements may be incorporated to upgrade the system.

\section{Key words}

RECORDS: anaesthetic;

STATISTICS: anaesthesia.

From the Department of Anaesthesiology/Critical Care Medicine, Hebrew University, Hadassah School of Medicine, Jerusalem, Israel.

Address correspondence to: Dr. Y. Weiss.

Accepted for publication 15th June, 1995.
Y.G. Weiss MD, S. Cotev MD, B. Drenger MD, R. Katzenelson MD
Cette présentation vise à déterminer sil est possible de recueiller avec un seul ordinateur et de rassembler automatiquement toutes les données médicales fournies par les systèmes accessibles à notre poste de travail du bloc opératoire (système de gestion des données médicales: SGDM). Notre approche est basée sur des informations extraites de la littérature médicale à partir de plusieurs systèmes déjà commercialisés. Trois d'entre eux ont été plus particulièrement étudiés (Informatics ${ }^{\circledR}$, Datex ${ }^{\circledR}$ et North American Drager(i)). Le SGDM devrait:

- capter et communiquer les renseignements obtenus de moniteurs et appareils utilisés en salle d'opération pour l'anesthésie, tout en affichant les chiffres et tendances sur un écran. - avertir l'anesthésiste de toute donnée anormale. A l'avenir, on devrait être en mesure à partir des données recueillies et d'un algorithme de créer un système qui permettra à l'anesthésiste de prendre des décisions.

- pouvoir communiquer avec l'ordinateur central de l'hôpital et transmettre automatiquement les données démographiques, les résultats de laboratoires et les dossiers de la visite préopératoires.

- A la fin de chaque opération, constituer un dossier comprenant les paramètres spécifiques à l'anesthésie recueillies automatiquement par le système ainsi que ceux que le médecin a introduits pendant lintervention; une copie de ce dossier serait conservée dans des archives informatisées.

Aucun des systèmes évalués ne remplit les conditions de notre SGDM. Les auteurs annoncent leur décision dintroduire ce système graduellement dans nos blocs opératoires en deux à cing ans.

For over two decades anaesthetists have contemplated the introduction of computerized patient data management systems (PDMS) into operating room (OR) practice. Today, the needs for the application of this technology look even more obvious. It is estimated that the typical 700-bed hospital in the industrialized countries produces more information daily than the London Stock Exchange. ${ }^{1}$ Therefore, computer technology is becoming in- 
dispensable to manage such a vast amount of information. More specifically, our monitoring instruments in the OR have become increasingly sophisticated, presenting the anaesthetist with vast quantities of real time numerical data (Table I). The integration of these accumulated data into our decision-making process is practically impossible in real time without the assistance of computer-based decision support systems. The rapid, on-going development of highly effective, and relatively inexpensive computer network systems and workstations has made the introduction of multiple workstations in the OR feasible. We believe, moreover, that PDMS has the potential to advance and upgrade our facility for quality assurance and risk management in anaesthesia. ${ }^{2}$ Cost containment may be expected as man-power in the OR is curbed to make money allocations in the health system more efficient.

In this report, we present an overview of the prospects, possibilities, and expected effects of PDMS technology on the workplace of anaesthetists. This presentation further aims to provide the reader with a tool to evaluate and compare available PDMS's before institutional decisions to computerize anaesthetic practice. We have examined several data management systems for the OR environment. Table II presents the main features of the three systems evaluated most extensively on-site in our operating rooms, namely DATEX AS/3 ${ }^{\circledR}$, Finland; North American Drager OR Data Manager ${ }^{\circledR}$, USA; and Informatics ${ }^{\circledR}$, UK.

We have identified and defined several important parameters for the evaluation and comparison of these and future systems that will be introduced.

\section{Interfacing}

The interfacing of the large variety of available instruments used in modern anaesthesia with the PDMS is one of the major problems in its immediate application. Weitzner's report ${ }^{3}$ on the standards for anaesthesia equipment which are being formulated by the European Economic Community (EEC) presents two PDMS concepts that had been accepted to tackle the interfacing issue. One concept is based on an integrated anaesthesia workstation which includes the anaesthesia machine, as well as most major monitoring devices, all assembled by one manufacturer. Manufacturers of PDMSs, however, were able to provide a feature enabling communication with most commonly used monitors in the OR (i.e., including those of other manufacturers). The other PDMS concept is that of a modular system which bridges a variety of commercially available monitors and anaesthesia machines likely to be present in one anaesthesia station into a working PDMS. Such a system includes the specific software and hardware to retrieve data from each individual device. The Committee on Technology of the Anes-
TABLE I Variables likely to be monitored in complicated patients in the perioperative period

\section{ECG}

ST segment analysis

Pulse oximetry

Non-invasive blood pressure

Invasive intra-arterial blood pressure

Capnography

Temperature

Central venous pressure

Pulmonary artery pressure

Pulmonary wedge pressure

Cardiac output

Mixed venous $\mathrm{O}_{2}$ saturation

Peripheral neuromuscular conduction

Fluid balance (in/out)

Haemoglobin/haematocrit/platelets

Anaesthesia machine parameters

Blood gases

Transoesophageal echocardiography (TEE)

Intracranial pressure

Jugular venous saturation

Electroencephalography

Evoked potentials (e.g., motor, sensory)

thesia Patient Safety Foundation has recently addressed the benefits of modularity. ${ }^{4}$ They concluded that modularity permits defining functions separately, allows future incremental upgrade with lower capital costs, helps ensure that interaction between parts of the system is addressed, 'speeds regulatory adaptation to change, allows more effective definition of data integration for processing and display, and finally, facilitates innovations. ${ }^{4}$ The users and makers of electronic anaesthesia instruments are becoming increasingly aware of the importance of providing tools for communication between the various components of the anaesthesia workstation. ${ }^{5,6}$ We believe that this trend is crucial in view of the continuous flow of new monitoring devices into the OR, such as the recently introduced tools for continuous measurement of cardiac output, intra-arterial blood gases and $\mathrm{pH}$, and transoesophageal echo (TEE) (Table II; items 5, 6, 7).

It is unfortunate that there are no standards of intercommunication common to all manufacturers of anaesthesia electronic equipment, although most companies provide for an RS232 output for computers. The introduction of a world-wide compatible interfacing standard system seems to be essential for the rapid and efficient introduction of PDMS in the OR.

\section{Information display and analysis}

Of the PDMSs that we had evaluated, most performed efficiently as automated anaesthesia record-keeping systems. These systems were devised to simulate the written anaesthesia record, presenting important monitoring data 
TABLE II Computerized patient data management systems evaluation

\begin{tabular}{|c|c|c|c|c|}
\hline & & $\begin{array}{l}\text { Informatics } \\
\text { Great Britain }\end{array}$ & $\begin{array}{l}\text { Datex } \\
\text { Finland }\end{array}$ & $\begin{array}{l}\text { North American Drager } \\
\text { U.S.A. }\end{array}$ \\
\hline 1 & Workstation hardware & $\begin{array}{l}\text { IBM PC or compatible } 486 \mathrm{DX} 2 \\
66 \mathrm{Mhz} .16 \mathrm{Mb} \text { of RAM } \\
\text { Windows } 3.11 \text {. }\end{array}$ & $\begin{array}{l}\text { AS/ } 3 \text { Monitor with real time operat- } \\
\text { ing system AMX }\end{array}$ & $\begin{array}{l}\text { Integral part of NAD Anesthesia } \\
\text { Machine. CPU: i486/66MHZ } \\
\text { RAM: } 8 \mathrm{MB}\end{array}$ \\
\hline & $\begin{array}{l}\text { Workstation network } \\
\text { system }\end{array}$ & Novell 3.12 & $\begin{array}{l}10 \text { Base-T Ethernet. Network server } \\
\text { with PC with DOS/WINDOWS/ } \\
\text { AMX }\end{array}$ & Banyan-Vines which is UNIX-based. \\
\hline 3 & Sampling rate and form & $\begin{array}{l}\text { Every } 15 \text { sec. A higher sampling rate } \\
\text { can be provided if required. The } \\
\text { value accepted is the instant-in-time } \\
\text { value. Sampling rate cannot be } \\
\text { changed by user during the case. }\end{array}$ & $\begin{array}{l}\text { Every minute - Median values re- } \\
\text { corded. Sampling rate cannot be } \\
\text { changed. }\end{array}$ & $\begin{array}{l}\text { Samples data every } 2.5 \mathrm{sec} \text {, but re- } \\
\text { cords and keeps the running median } \\
\text { every } 30 \mathrm{sec} \text {, with exception of NIBP } \\
\text { and } C O \text {. The sampling rate cannot } \\
\text { be changed. }\end{array}$ \\
\hline 4 & Information backup & $\begin{array}{l}1 \text { Local workstation continuously } \\
\text { copies all data reconded locally to } \\
\text { the server. } \\
2 \text { Data is backed up from the server } \\
\text { every night to a storage device. } \\
3 \text { A copy of the data is kept on the } \\
\text { workstation for } 14 \text { days before dele- } \\
\text { tion. }\end{array}$ & $\begin{array}{l}1 \text { PCMCIA Card on monitor keeps } \\
\text { data for } 48 \mathrm{~h} \text {. } \\
215 \text { min battery backup RAM in } \\
\text { the monitor. } \\
32-4 \text { wk data storage, via NOVELL } \\
\text { on Anesthesia Information Center } \\
\text { Hard Disk. } \\
4 \text { Longterm data archiving through } \\
\text { the Novell server connected to the } \\
\text { Anesthesia Information Center. }\end{array}$ & $\begin{array}{l}1 \text { To the network file server. } \\
2 \text { Locally, to the hard disk drive of } \\
\text { the OR Data Manager for up to } \\
100 \text { cases on a floppy disk drive. } \\
3 \text { Backup of the files on the server's } \\
\text { hard disk are done daily by a DAT } \\
\text { tape drive integrated in the file } \\
\text { server. }\end{array}$ \\
\hline & $\begin{array}{l}\text { Interfacing - digital/ } \\
\text { analogue }\end{array}$ & $\begin{array}{l}\text { Both digital and analogue } \\
\text { (Monitor List Appendix). }\end{array}$ & $\begin{array}{l}\text { Both digital and analogue } \\
\text { (Monitor List Appendix). }\end{array}$ & $\begin{array}{l}\text { The interfaces are digital. } \\
\text { (Monitor List Appendix). }\end{array}$ \\
\hline 6 & $\begin{array}{l}\text { No. of parameters } \\
\text { recorded simultaneously }\end{array}$ & 32 parameters. & All AS/3 parameters. & 37 parameters. \\
\hline 7 & $\begin{array}{l}\text { Number of monitors } \\
\text { interfaced } \\
\text { simultaneously }\end{array}$ & $\begin{array}{l}\text { A maximum of } 32 \text { serial devices can } \\
\text { be interfaced simultaneously. The } \\
\text { number of analogue devices limited } \\
\text { by number of slots available on } \\
\text { workstation. }\end{array}$ & $\begin{array}{l}\text { Via an interface board it can connect } \\
\text { simultaneously to } 8 \text { other devices. }\end{array}$ & $\begin{array}{l}3 \text { monitors and } 3 \text { syringe pumps si- } \\
\text { multaneously. }\end{array}$ \\
\hline 8 & $\begin{array}{l}\text { Data presentation } \\
\text { No. of parameters } \\
\text { presented simultane- } \\
\text { ously }\end{array}$ & $\begin{array}{l}\text { Currently } 26 \text { parameters. More can } \\
\text { be provided. }\end{array}$ & $\begin{array}{l}\text { All AS/ } 3 \text { parameters: } 6 \text { in analogue } \\
\text { and numerical presentation, and } 4 \\
\text { digital on one screen. }\end{array}$ & $\begin{array}{l}\text { Currently: graphically displayed - } 8 \text {; } \\
\text { numerically displayed }-7 \text {. To be in- } \\
\text { creased to } 12 \text { in the next release. }\end{array}$ \\
\hline 9 & $\begin{array}{l}\text { Connectivity to } \\
\text { mainframe computer: } \\
\text { - demographic data } \\
\text { - laboratory data }\end{array}$ & $\begin{array}{l}\text { Existing. Needs collaboration with } \\
\text { computer division. }\end{array}$ & $\begin{array}{l}\text { Input/Output Toolbox provided (ex- } \\
\text { pected to be released 1995). All inter- } \\
\text { facing by hospital personnel. }\end{array}$ & $\begin{array}{l}\text { Possible; requires collaboration be- } \\
\text { tween NAD and hospital personnel. }\end{array}$ \\
\hline 10 & $\begin{array}{l}\text { Artifacts } \\
\text { - Rejection } \\
\text { - Deletion } \\
\text { - Manual entry }\end{array}$ & $\begin{array}{l}\text { Range checking as modality of rejec- } \\
\text { tion. Artifacts marked by entering an } \\
\text { "event." No modality for deletion of } \\
\text { recorded artifact. }\end{array}$ & $\begin{array}{l}\text { AS/ } 3 \text { Internal artifact rejection - } \\
\text { e.g., flushing of A-Line etc. Manual } \\
\text { entry possible. }\end{array}$ & $\begin{array}{l}1 \text { A custom key on the keyboard la- } \\
\text { beled artifact. } \\
2 \text { Data automatically recorded can- } \\
\text { not be deleted. }\end{array}$ \\
\hline 11 & Modality of data entry & $\begin{array}{l}\text { Key-board, trackball, light-pen, } \\
\text { touch-screen. }\end{array}$ & $\begin{array}{l}\text { Dedicated keyboard with the com- } \\
\text { wheel. }\end{array}$ & $\begin{array}{l}\text { Two data entry modalities: } \\
1 \text { Customized keyboard embedded } \\
\text { into the writing tray. } \\
2 \text { DataGrip device. }\end{array}$ \\
\hline 12 & $\begin{array}{l}\text { Preoperative evaluation } \\
\text { programme }\end{array}$ & Already existing. & $\begin{array}{l}\text { Shortly, in the coming version of the } \\
\text { system. }\end{array}$ & Already existing. \\
\hline
\end{tabular}


TABLE II Computerized patient data management systems evaluation (continued)

\begin{tabular}{|c|c|c|c|}
\hline & $\begin{array}{l}\text { Informatics } \\
\text { Great Britain }\end{array}$ & $\begin{array}{l}\text { Datex } \\
\text { Finland }\end{array}$ & $\begin{array}{l}\text { North American Drager } \\
\text { U.S.A. }\end{array}$ \\
\hline $\begin{array}{l}13 \text { Package for data } \\
\text { analysis/export }\end{array}$ & $\begin{array}{l}\text { All patient data are available in } \\
\text { DBase format, and this can be con- } \\
\text { verted for export in ASCII format. } \\
\text { The system incorporates additional } \\
\text { software for data analysis. }\end{array}$ & $\begin{array}{l}\text { Input/Output toolbox provided (ex- } \\
\text { pected to be released in 1995). Con- } \\
\text { sidering making an analyzing soft- } \\
\text { ware in the future. The first product } \\
\text { will be a Resources Management } \\
\text { software. }\end{array}$ & $\begin{array}{l}\text { All data captured can be analyzed in } \\
30 \text { sec intervals, in a spreadsheet or } \\
\text { graphical format. Information can be } \\
\text { converted and exported into other } \\
\text { formats (DBase, ascii etc.) NAD's } \\
\text { data management system includes } \\
\text { the Clinical Data Analysis Software } \\
\text { (CliniDAS) with the following soft- } \\
\text { ware modules: PC Prep/View, Im- } \\
\text { port/Query, OR Utilization, Drug } \\
\text { Utilization, Quality Assurance. }\end{array}$ \\
\hline 14 Security features & $\begin{array}{l}1 \text { The software is password pro- } \\
\text { tected. } \\
2 \text { Novell is password protected. }\end{array}$ & $\begin{array}{l}\text { Existing features to prevent illegal } \\
\text { entry into the system and illegal in- } \\
\text { formation retrieval. }\end{array}$ & $\begin{array}{l}1 \text { Username and password to log } \\
\text { onto any workstation. } \\
2 \text { Different levels of staff rights as- } \\
\text { signed to each user. } \\
3 \text { Security levels on the network oper- } \\
\text { ation system to prevent unautho- } \\
\text { rized access. }\end{array}$ \\
\hline
\end{tabular}

(e.g., pulse oximetry, heart rate, blood pressure, anaesthesia and respiratory gas concentrations) on the screen (Table II, item 8). Other screens in such a system allow manual recording of data such as patient demographics, drugs, and fluids. The user employs a key-board, mouse, optical pen, touch screen, bar-code system, or a combination of these devices to enter data and navigate between the different screens (Table II; item 11). Some systems enable the physician to see, on a single screen, all relevant information from the different monitors, including manually entered data, by navigating with a mouse on the screen (e.g., Informatics). In order to save time, in all systems, manually entered information is automatically adjusted on the time-axis. The information entered manually should do so through preconfigured coded lists. " Free text should be possible, but kept to a minimum. In order to adhere to this goal the preconfigured lists should be prepared meticulously in advance, and continuously adapted to the anaesthetist's needs. This can be done by creating personal preconfigured tables or, the option we chose, creating a library of specific tables for a variety of anaesthetic procedures, or a combination of both. In our opinion, the display of the on-line anaesthesia data need not resemble previous anaesthesia charts; instead, the main screen should focus and accentuate the most important real time data, in a numerical and/or graphical manner. ${ }^{7}$

Only one of the PDMSs (IdaCare ${ }^{\circledR}$, Hermes Systems, Belgium), that we had examined includes a statistical programme enabling basic analysis of data obtained in real time. We believe that a PDMS should first integrate all the relevant information from the various monitors and anaesthesia instruments, and secondly support on-line analysis of that information. Such analysis will facilitate the introduction, in the future, of integrated alarms, and decision-support systems to assist the anaesthetist. ${ }^{8}$ By recognition and analysis of patterns of vital signs and trends, integrated alarm systems will provide early detection of impending crisis, in advance of possible catastrophe. ${ }^{9}$

A variety of hypermedia electronic textbook products (e.g., Micromedix Inc, Micromedix, Colorado; Physician's Desk Reference etc.), is becoming available in clinical medicine with a range of on-line information files, including those on drug interaction, dosage and toxicity. Hypermedia allows navigation in a "virtual document" composed from a variety of primary sources linked by the user. ${ }^{10}$ Such computerized decision-support systems, integrated with hypermedia software may replace the pocket handbooks, or wall charts which are so popular in our operating rooms.

\section{Data acquisition}

Data acquisition during an anaesthetic sequence should be so frequent as to capture as many as possible of the important events in each monitored parameter and in each stage of the procedure. We view the computer as a "black box" in which voluminous amounts of data are stored, which can be easily retracted and analyzed retrospectively whenever necessary. Nevertheless, the ideal frequency for data acquisition is unknown, and has been suggested to be between every five minutes, as usual in 
today's manual record, to as frequently as every $15 \mathrm{sec} . "$ The available systems differ in their approach as to which value should be recorded ${ }^{12}$ (Table II; item 3 ). Some present the on-line value as it is obtained. The trend however, is towards recording the median of multiple samples acquired during an epoque. It is important to include an option which enables the anaesthetist to determine the frequency of acquiring on-line data, depending on the dynamics of evolving events. We expect this feature to be useful specifically during critical parts in the course of anaesthesia such as the induction period, or instances of physiological instability. Not one of the systems that we had evaluated incorporated such a feature.

The PDMS should automatically backup the information recorded in order to prevent accidental loss of information in cases of power failure (Table II; item 4).

\section{Computer networking}

Each station in an individual operating room is independent, but must be linked to the other stations by a Local Area Network (LAN). It is important that the LAN in the operating room is planned to interface via a "bridge" to the computer network connecting the hospital's wards, laboratories, and imaging facilities. The patient's preoperative evaluation by the anaesthesia staff takes place in specific clinics or in the different wards. That same network should include stations in the preoperative clinics, the postanaesthesia care unit (PACU), and the intensive care unit (ICU) for postoperative follow up (Table II; item 12). It should also connect with the different laboratories and imaging departments to facilitate the total perianaesthetic care. We favour a network that will also enable a department head, or a designated senior anaesthetist, to provide advice to the attending physician during anaesthesia, without necessarily being in the operating room (i.e., the "big brother" facility), while having the entire up-to-date anaesthesia record available to him on his own computer screen.

In such a network a separate workstation can provide a statistical package for clinical research, quality assurance and accounting (Table II; item 13). Networking will also facilitate the introduction of software (not available today) for real time data analysis to enable intelligent alarms and integration with multimedia systems.

The goal in operating a quality assurance programme is to improve patient safety and outcome. Ideally, the PDMS will give the potential opportunity to share data from multiple institutions, especially those using the same PDMS, and to perform meaningful analysis of outcome. ${ }^{13}$

\section{Archive systems - information coding and keeping}

For the department interested in PDMS, two important questions arise. The first is how the privacy of the patient and secrecy of the medical file can be protected. This can be provided by using passwords, by separating the PDMS computer from all other hospital computers, and by scrambling the data saved. Any one, or a combination of these precautions, must be imposed (Table II; item 14). The second question is how to manage the information in the PDMS so as to enable the prompt retrieval of the necessary information at a later date. We have agreed on several guidelines to tackle this question. Each patient's anaesthesia record can be kept on a computerized library, using large hard or optic disks that can be immediately accessed by staff of the department. Some essential and important data from the anaesthesia record should be transferred to the hospital computer. We aim to introduce tools which convert parts of the data into ASCII files to allow free manipulation of relevant data by a large array of software packages for research purposes.

\section{Artifact recognition}

An important problem in the use of PDMS, based on automatic on-line acquisition of monitored data, is the handling of artifacts due to mechanical or electrical disturbances ${ }^{14}$ (Table II; item 10). A partial solution lies in understanding that the role of the PDMS is not to replace monitors but, rather, to centralize the information obtained from the different monitors in a "friendlier" and more comprehensive fashion. The monitors, and not the PDMS, should be increasingly equipped with signal validation techniques such as state of the art filtering devices (i.e., electrode impedance for ECG monitoring, or intelligent artifact rejection schemes as in the Datex AS/3 that recognizes when the invasive pressure system is being flushed). Because the PDMS acquires information from all monitoring devices, it can be used as a computerbased supervisor that identifies certain artifacts by online comparison of information retrieved from different monitors/parameters. ${ }^{15}$

In order to keep the legal credibility of the PDMS files, deletion of artifacts from these files should not be permitted, although these guidelines are controversial. ${ }^{16}$ The artifacted records should remain intact, accompanied by comments and data entered manually by the physician. The rejected data should be tagged with the identity of the operator and the date and time of the rejection. Some systems employ a special key to mark artifacts (i.e., NAD OR Data Manager).

\section{The printed anaesthesia record}

Unfortunately, during the period when patient care is most intense and demands the most attention from the clinician, the record is, at best, incomplete. Therefore, the least accurate record corresponds to the periods at which 
the patient is subject to important and rapid physiological changes, and when profound pharmacological intervention may occur. The automated anaesthesia record should eliminate these seemingly inevitable occurrences.

The information concerning medications and fluid balance administered during anaesthesia should be presented on the same spread-sheet report, below the on-line recorded vital-signs and parameters, and synchronized on a common time-axis. This is essential to allow intelligent analysis and evaluation of physiological, as well as abnormal events during the operation.

\section{Customization}

Customization and flexibility are important provisions for the successful implementation of the elaborate computerized PDMS in the OR of a large tertiary hospital. The system should be able to adapt to the changing requirements and anaesthesia standards for many different surgical procedures and anaesthetic plans, as well as for newly introduced surgical procedures and anaesthetic techniques. Similarly, the PDMS should accommodate to a multitude of users, each with their own anaesthetic protocols for every surgical procedure. Good computer software grows and adapts to the changing needs of the user. Therefore, it is imperative for the manufacturers entering this field to realize that they commit themselves to a long-lasting partnership of constant exchange of ideas and demands with the users.

\section{Human - machine (computer) interface}

Physicians are likely to be apprehensive of new systems and wary of losing control to electronic systems. As suggested by Woods, in evaluating new technology, one should not evaluate the new box, but rather the personmachine system. ${ }^{15}$ Thus, the PDMS should be easy to use and, after proper training its operation, should not be more complicated than properly filling the manual record. ${ }^{6,17,18}$ In order to improve acceptance of the system by the department's staff, the latter should be extensively involved in the planning and implementation of the PDMS. ${ }^{19}$ Furthermore, our impression is that an anaesthetist should act as the coordinator of the system. Our experience so far with most available PDMSs has been that, due to the relative user-friendliness of the systems, it took most of us, even those not especially familiar with the PC or Macintosh, only a day or two to familiarize ourselves with these systems and to implement them. Nevertheless, the systems available today need improvement in the aspect of information entry. This becomes most prominent during and immediately after periods of high intensity work, such as the induction of anaesthesia. Information entry after such a period, when several, often-critical, events occur, simultaneously with the administration of a variety of drugs, is very cumbersome. For a system to be of value for the physician, it has to be superior to the hand-written anaesthesia record, rather than creating new problems and new errors. ${ }^{15}$

Critics of automated record-keeping systems claim that they distract the clinician's attention during low-workload, uneventful periods. They claim that the task of periodically writing down the measured vital signs keeps the physician concentrated on the patient's condition. This phenomenon is coined "situation awareness" by human engineering specialists. ${ }^{15}$ Two recent studies, however, demonstrated the beneficial effect of PDMS on anaesthesia vigilance. Loeb demonstrated that anaesthesia residents were equally attentive to a signal displayed on an electronic monitor during manual charting, as they were when an assistant kept the record. ${ }^{20}$ Herndon et al. showed a tendency towards slightly faster response times while using PDMS in detecting a vigilance signal (alarmlike signal) among anaesthesia residents during cardiac surgery. ${ }^{21}$

\section{Ergonomics}

Contemporary operating rooms are often excessively crowded. Careful pre-planning of how and where to install the PDMS is therefore advised. Eventual acceptance of a PDMS by the staff may be influenced by space and location considerations, such as the placing of the computer's CPU, the positioning of the monitor on the anaesthesia machine, or on a separate trolley, etc. Some systems are equipped with a flat rotating screen, enabling the anaesthetist to view and follow the presented data conveniently. A large flat monitor, presenting most of the relevant information on one screen, seems to be far superior and acceptable.

Several companies propose to adapt from the aviation industry a small display of data mounted a few centimeters from the eyes, while others have developed voice activated systems. ${ }^{22}$ The combination of these two technologies will allow continuous viewing of the patient's vital signs, while keeping constant contact with the patient and the surgical field.

At the Anesthesia Patient Safety Foundation (APSF) 1992 Annual Meeting, a group comprised of anaesthetists, engineers, nurse anaesthetists, technicians, industrial executives and individuals with background in marketing, met to focus on the future design of the anaesthesia workstation. ${ }^{23}$ All participants agreed on the importance of functional integration, with the use of computers in data management and process control, especially for data display and record keeping. Emphasis was given to the position of the anaesthetist in an ergonomically efficient environment for viewing and controlling both the patient and the various monitors. 


\section{Ethical and legal issues}

The PDMS must provide the tools to safeguard the secrecy of the gathered data of any patient, and yet make the data easily retrievable to select users of the system, such as the anaesthetist about to manage a subsequent anaesthetic on the patient (Table II; item 14). The system should be protected by a username and an encrypted password. Each data item entered manually will be tagged with the username and time. The system and its data must be made inaccessible from unauthorized workstations in the hospital's network.

Another issue evolves around legal liability imposed on the user of the PDMS. It is still not clear whether the availability of on-line, automatically recorded and unerasable data will impose additional liability on the user, or rather relieve it in instances of untoward events during surgery. The pendulum, however, seems to be moving towards the acceptance of PDMS as a protecting tool under such circumstances. ${ }^{17}$ From the medicolegal perspective, PDMSs have the advantage of creating a legible and accurate record of the anaesthetic, and its effect on the patient, as assessed by standard monitoring. ${ }^{24,25}$ Courts have taken a dim view of records based on data that was retrospectively recollected from memory following periods of intense and hectic activity. ${ }^{26}$ Such records are presumably inaccurate, are usually illegible, and unclear. ${ }^{26}$ The anaesthetist cannot be expected to administer anaesthesia while at the same time continuously monitoring the patient and document the process in its entirety. Some malpractice insurance companies are offering incentives to physicians using such systems, suggesting an element of legal protection. ${ }^{27}$

\section{Conclusion}

It is estimated that, at present, some $10-12 \%$ of the anaesthetist's time during surgery is spent on the manual recording of data, while $59 \%$ is devoted to monitoring the patient, either directly or indirectly. ${ }^{28}$ The PDMS, by automating data acquisition, and improving data presentation, will enable the physician to spend more time on clinical monitoring and management of the patient, although this has never been proved. Furthermore, these systems may optimize clinical decision-making and improve quality assurance evaluation and risk management programmes. ${ }^{2}$ The PDMS will replace the frequently illegible and inaccurate records of today with legible charts, containing more higher quality information. ${ }^{29,30}$ Future computer technologies, such as the head-mounted screen, voice activation, bar codes and others, should help to optimize the real time human-computer interaction, and, at the same time, the convenient presentation of information.

The PDMS should also be able to support the creation of simulator software from a library of archived recorded events for training in anaesthesia. ${ }^{31}$

A well-conceived PDMS should integrate all relevant data acquired from the various monitors and the anaesthesia machine on one screen. This will create momentum for the introduction, in the future, of integrated, smart alarm modes, and decision support systems to assist the anaesthetist. ${ }^{8}$ By recognition and analysis of vital sign patterns and trends, integrated alarm systems will provide early detection of impending disaster.

Finally, PDMS may be defined as an emerging technology: ${ }^{32}$ a technology that is on the horizon, as yet unproven, but potentially extremely important. We should not underestimate the virtues of this technology, which we believe will prove itself in the next decade.

\section{Acknowledgements}

We wish to thank the manufacturers and their representatives in Israel who participated in this trial for their efforts and cooperation.

\section{Appendix}

List of "Foreign" monitor manufacturers that can interface with the following systems

\section{INFORMATICS \\ Baxter \\ Critikon \\ Datex \\ Drager \\ Hellige \\ Hewlett Packard \\ Ohmeda \\ Marquette \\ Siemens \\ Spacelabs}

\section{DATEX}

Nellcor pulse oximeter

Critikon Dynamap 1846c NIBP

Oximetrix $\mathrm{SVO}_{2}$ Monitor

\section{NA DRAGER}

Criticare

Datex

Datascope

Hewlett Packard

Marquette

Siemens

Spacelabs

Nellcor

Puritan Bennet 


\section{References}

1 Research and technology development on telemetric systems in health care. Commission of the European Communities, Telematics for health care (AIM) 1988-1990. Office for official publications of the European communities, Luxembourg.

2 Edsall $D W$. Quality assessment with a computerized anesthesia information management system (AIMS). QRB Quality Review Bulletin 1991; 17: 182-93.

3 Weitzner $S$. European "Workstation" rules will influence U.S. anesthesia machines. Anesthesia Patient Safety Foundation 1992; 7: 2-6.

4 The Committee on Technology, Anesthesia Patient Safety Foundation. Critical issues relating standards for technology to patient safety. J Clin Monit 1994; 10: 296-303.

5 Shabot MM. Standardized acquisition of bedside data: The IEEE P1073 medical information bus. Int J Clin Monit Comput 1989; 6: 197-204.

6 Edsall DW, Deshane P, Giles C, Dick D, Sloan B, Farrow $J$. Computerized patient anesthesia records: less time and better quality than manually produced anesthesia records. J Clin Anesth 1993; 5: 275-83.

7 Friesdorf $W$, Schwilk $B$. Patient-related data management. J Clin Monit 1992; 8: 308-14.

8 Shortliffe EH. Computer programs to support clinical decision making (Letter). JAMA 1987; 258: 61-6.

9 Mylrea KC, Orr JA, Westenskow DR. Integration of monitoring for intelligent alarms in anesthesia: neural networds - can they help? J Clin Monit 1993; 9: 31-7.

10 Conklin J. Hypertext: an introduction and survey. Computer 1987; 20: 17-41.

11 Gravenstetin JS, de Vries A, Beneken JEW. Sampling intervals for clinical monitoring of variables during anesthesia. J Clin Monit 1989; 5: 17-21.

12 Gardner RM, Prakash $O$. Challenges and opportunities for computerizing the anesthesia record. J Clin Anesth 1994; 6: 333-41.

13 Feldman $J M$. Anesthesia recordkeepers into the next century. ASA Newsletter 1993; 57: 24-8.

14 Schwilk $B$, Friesdorf $W$. Informatic systems in anesthesia, Current Opinion in Anesthesia 1991; 4: 838-42.

15 Westenskow $D R$. Understanding and avoiding artifacts. Seminars in Anesthesia 1991; 1: 15-21.

16 Westenskow DR. Should the user be able to alter the computerized anesthesia record? Medical Innovations Quarterly Review 1989; 1: 3-5.

17 Kassing $D R$, Anderson JG. Overcoming barriers to computerization of information management. ASA Newsletter 1993; 57: 29-33.

18 Abenstein JP, De Vos CB, Tarhan A, Tarhan S. Eight years' experience with automated anesthesia record keeping: lessons learned - new directions taken. Int J Clin Monit Comput 1992; 9: 117-29.
19 Anderson JG, Jay SJ, Perry J, Anderson MM. Modifying physician use of a hospital information system: a quasiexperimental study. In: Anderson JG, Aydin CE, Jay SJ (Eds.). Evaluating Health Care Information Systems: approaches and Applications. Thousand Oaks, CA: Sage Publications; 1993.

20 Loeb $R G$. Manual record keeping is not necessary for anesthesia vigilance. J Clin Monit 1995; 11: 9-13.

21 Herndon OW, Weinger MB, Zornow MH, Gaba DM. The use of automated record keeping saves time in complicated anesthetic procedures. Anesth Analg 1993; 76: S140.

22 Smith NT, Brien RA, Pettus DC, Jones BR, Quinn $M L$, Sarnat $A$. Recognition accuracy with a voice-recognition system designed for anesthesia record keeping. J Clin Monit 1990; 6: 299-306.

23 Calkins JM. Update of STA 1992: the anesthesia workstation. J Clin Monit 1994; 10: 293-5.

$24 \mathrm{Kroll} D A$. The legal implications of computerized anesthesia records: an admittedly biased review. Seminars in Anesthesia 1991; 10: 30-5.

25 Thrush $D N$. Are automated anesthesia records better? J Clin Anesth 1992; 4: 386-9.

26 Gibbs $R F$. The present and future medicolegal importance of record keeping in anesthesia and intensive care: the case for automation. J Clin Monit 1989; 5: 251-5.

27 Schoenstadt DA. Computerized anesthesia records: an insurance company's perspective. Seminars in Anesthesia 1991; 10: 41-7.

28 McDonald JS, Dzwonczky $R$. A second time study of the anesthetist's intraoperative period. Br J Anaesth 1990; 64: 583-5.

29 Cook RI, McDonald JS, Nunziata E. Difference between handwritten and automatic blood pressure records. Anesthesiology 1989; 71: 385-90.

30 Hammond J, Johnson HM, Varas $R$, Ward CG. A qualitative comparison of paper flowsheets vs a computer-based clinical information system. Chest 1991; 99: 155-7.

31 Gaba DM. Improving anesthesiologists' performance by simulating reality (Editorial). Anesthesiology 1992; 76: 491-4.

32 Adler PS, Sbenbar $A$. Adapting your techological base: the organizational challenge. Sloan Management Review, Fall 1990; 25-37. 